\title{
BENANG MERAH TERBENTUKNYA POLA PERMUKIMAN DAN POLA HUNIAN DESA BALI MULA DIKAITKAN DENGAN ASPEK SOSIAL, EKONOMI DAN BUDAYA STUDI KASUS: DESA PAKRAMAN JULAH, KECAMATAN TEJAKULA, BALI
}

\author{
Ari Widyati Purwantiasning \\ Program Studi Arsitektur Fakultas Teknik Universitas Muhammadiyah Jakarta \\ arwityas@yahoo.com
}

\begin{abstract}
ABSTRAK. Desa Pakraman Julah merupakan salah satu desa adat tertua di Bali, desa ini sudah ada pada tahun caka 844 pada masa pemerintahan Sang Ratu Sri Ugrasena di Bali. Desa Pakraman Julah ini tepatnya terletak di Kecamatan Tejakula, Bali. Desa ini mempunyai keunikan tersendiri, dari adat istiadat, kebudayaan dan juga arsitektur yang dimilikinya seperti pola permukiman dan pola huniannya. Penelitian ini mengangkat permasalahan mengenai sejauh mana aspek sosial, ekonomi dan budaya mempengaruhi dan berkaitan erat dengan terbentuknya pola permukiman dan pola hunian di Desa Pakraman Julah ini. Pola permukiman pada Desa Pakraman Julah ini terbentuk karena didasari oleh adanya konsep "Nyegara Gunung", yang ada di dalam adat istiadat dan filsafat masyarakat Bali. Di dalam filosofi Bali "Nyegara Gunung" adalah bahwa elemen antara laut dan gunung tidak dapat dipisahkan, dan menjadi satu kesatuan yang sejajar dan saling mendukung satu sama lainnya. Sementara itu pola hunian yang ada di dalam masyarakat Desa Pakraman Julah terbentuk karena adanya konsep "Rwa Bhineda" yaitu dua elemen/ hal yang bertentangan seperti: luan-teben; sakral-profan, huluhilir; utara-selatan; positif-negatif; dan sebagainya. Pola permukiman dan pola hunian yang terbentuk di dalam kehidupan masyarakat Desa Pakraman Julah maupun desa adat lainnya di Bali, tentunya secara tidak langsung di pengaruhi oleh aspek sosial, ekonomi dan budaya yang dimiliki oleh masyarakat tersebut. Di dalam penelitian inilah akan dikaji lebih dalam mengenai kaitan dan hubungan timbal balik antara terbentuknya pola permukiman dan pola hunian di Desa Pakraman Julah ini dengan aspek sosial, ekonomi, dan budayanya. Penelitian ini menggunakan metode kualitatif komparatif yang mengedepankan pendekatan deduktif dalam analisis pembahasannya.
\end{abstract}

Kata Kunci: pola permukiman, pola hunian, aspek sosial, aspek ekonomi, aspek budaya

ABSTRACT. Desa Pakraman Julah is one of the old traditional villages in Bali. This village has existed since 844 year of caka, during the reign of Queen Sri Urgrasena in Bali. Pakraman Julah Village is precisely located in Tejakula District, Bali. This village has its own uniqueness, from customs, culture and also its architecture such as the pattern of settlements and patterns of the dwelling. This study raises the issue of the extent to which social, economic and cultural aspects affect and is closely related to the formation of settlement patterns and patterns of the dwelling in this Pakraman Julah Village. The pattern of settlement in Pakraman Julah Village is formed because it is based on the concept of "Nyegara Gunung", which is in the customs and philosophy of Balinese society. In the Balinese philosophy "Nyegara Gunung" is that the elements between sea and mountain cannot be separated, and become a unity parallel and mutually supportive of each other. Meanwhile, the pattern of occupancy that existed in the community of Pakraman Julah Village was formed because of the concept of "Rwa Bhineda" ie two elements/ contradictory things such as luan-teben (outside-inside); sacred-profane, upstreamdownstream; north-south; positive-negative; etc. The pattern of settlements and pattern of the dwelling that formed in the life of the community of Pakraman Julah Village and other traditional villages in Bali, of course, indirectly influenced by social, economic and cultural aspects of the community. In this research will be studied more deeply about the relationship and reciprocal relationship between the formation of settlement patterns and pattern of the dwelling in this Pakraman Julah Village with the social, economic, and cultural aspects. This study uses a qualitative comparative method that puts forward the deductive approach in the analysis of the discussion.

Keywords: pattern of settlement, pattern of dwelling, social aspects, economic aspects, cultural aspects

\section{PENDAHULUAN}

Bali merupakan salah satu Provinsi yang ada di Indonesia yang kaya akan adat istiadat dan keanekaragaman budayanya. Selain memiliki keindahan alam, Bali juga memiliki banyak desa adat tradisional yang setiap desa tersebut mempunyai tradisi-tradisi dan kebudayaan yang menjadi ciri khas desa adat tersebut. Salah satu desa adat tradisional di Bali yang termasuk salah satu desa adat tertua adalah desa adat Julah.

Desa adat Julah merupakan desa adat yang perkembangannya tidak terlepas dari pengaruh kebudayaan Bali Mula, yaitu kebudayaan awal terlahirnya kebudayaan Bali. Desa ini sudah ada pada tahun caka 844 atau tanggal 24 Januari 923 masehi pada masa pemerintahan Sang Ratu Sri Ugrasena di Bali [1]. Desa adat Julah memiliki keunikan tersendiri daripada desa adat Bali lainnya. Memiliki adat istiadat yang berbeda, memiliki pola permukiman dan pola hunian yang berbeda pula. Bentuk pola permukiman dan pola hunian yang dimiliki desa adat Julah yang berbeda dengan desa adat lainnya tentunya tidak terlepas dari pengaruh aspek sosial, ekonomi dan budaya. Pada penelitian ini, permasalahan yang akan diangkat adalah 
bagaimana keterkaitan antara terbentuknya pola hunian dan pola permukiman dengan aspek sosial, ekonomi dan budaya dari masyarakat Desa Pakraman Jula, Bali.

\section{TUJUAN PENELITIAN}

Penelitian ini bertujuan untuk:

1. Mengidentifikasi pola permukiman yang ada di Desa Pakraman Julah

2. Mengidentifikasi pola hunian yang ada di Desa Pakraman Julah

3. Mengidentifikasi aspek non fisik yaitu aspek ekonomi, sosial dan budaya dari masyarakat Desa Pakraman Julah

4. Mengkaitkan pengaruh aspek ekonomi, sosial dan budaya masyarakat Desa Pakraman Julah dengan terbentuknya pola hunian yang ada di Desa Pakraman Julah

5. Mengkaitkan pengaruh aspek ekonomi, sosial dan budaya masyarakat Desa Pakraman Julah dengan terbentuknya pola permukiman yang ada di Desa Pakraman Julah

\section{FILOSOFI ARSITEKTUR BALI}

Arsitektur Bali sejatinya telah dibekali banyak lontar yang berkaitan dengan arsitektur. Ada lontar Asta Patah yang terkait dengan ukuran dan jarak tiang bangunan. Swakarma perihal tata cara menebang kayu, Padmabhumi yang menyangkut sejarah lokasi pura-pura di Bali berlandaskan pengider-ideran pada bhuana agung. Janantaka tentang klasifikasi kayu yang hendak digunakan untuk bangunanbangunan suci maupun umah $[2,3]$.

Kemudian ada lontar tentang Sikuting Umah, berhubungan dengan pengukuran bangunan perumahan. Lainnya, ada Bhuana Kretih, terkait upacara-upacara dalam proses mendirikan bangunan sejak awal hingga selesai. Ada pula Dewa Tatwa yang mengulas jenis- jenis sesajen atau pedagingan untuk masing-masing palinggih dan jenis-jenis upacara pamelaspas. Intinya, semua itu boleh dikata sebagai "tutur-tutur" yang mengingatkan kembali, agar orang-orang senantiasa mensyukuri, menghormati dan memberi keseimbangan pada alam, tidak mengeksploitasi. Selain tetap eling dan bakti pada Hyang Pencipta serta kasih saying pada sesama makhluk ciptaan-Nya.

Dengan adanya pemahaman dalam pemaknaan arsitektur yang benar dan baik tentu nantinya akan dapat memberikan pengaruh terhadap kesantunan berkarya arsitektur di Bali. Kesantunan sebagai bingkai kejujuran, transparansi pengutaraan dan penciptaan ruang-ruang yang beretika dalam format nalar dan cita rasa yang kreatif hendaknya semakin mengakar dan membumi. Boleh jadi, pemahaman itu akan bermuara pada tafsir yang lebih bijak dan arif terhadap keberagaman arsitektur Bali itu sendiri. Maka sepatutnya, jangan seragamkan kekhasan arsitektur lokal yang satu dengan lainnya di tempat berbeda.

Keberagaman menunjukkan kekayaan local geniusnya. Arsitektur hunian vernacular Bali maupun tempat peribadatan (parhyangan) yang ditata dalam sebuah desa, masingmasing wilayah memiliki pola-pola khas yang unik. Misalnya ada pola desa-berarsitektur khas- Sembiran, Sukawana, Sidatapa, Julah, Tenganan, Pengotan, Kekeran, Jatiluwih, Tengkudak, Wongaya Gede, Bugbug, Tihingan, Nyalian, Legian, Bayung Gede, dan masih banyak lagi. Begitu pula tatanan ruang dan masa bangunannya, punya keunikan masing-masing.

Di Bali saat ini ditemukan berbagai corak arsitektur, mulai dari Arsitektur tradisional bali kuno, tradisional bali yang di kembangkan, arsitektur masa kini yang bergaya bali bahkan arsitektur yang sama sekali tidak memiliki nuansa bali. Mengetahui aspek-aspek arsitektur tadisional Bali di butuhkan pengetahuan yang mendalam terutama aspek filosofi, religius dan sosial budaya.

Arsitektur tradisional Bali dapat diartikan sebagai tata ruang dari wadah kehidupan masyarakat Bali yang telah berkembang secara turun-temurun dengan segala aturanaturan yang diwarisi dari jaman dahulu, sampai pada perkembangan satu wujud dengan ciriciri fisik yang terungkap pada lontar Asta Kosala-Kosali dan Asta Pasali [2]. Arsitektur Tradisional Bali yang memiliki konsepsikonsepsi yang dilandasi agama Hindu, merupakan perwujudan budaya, dimana karakter perumahan tradisional Bali sangat ditentukan norma-norma agama Hindu, adat istiadat serta rasa seni yang mencerminkan kebudayaan.

Arsitektur Tradisional Bali memiliki beberapa konsep-konsep dasar yang mempengaruhi nilai tata ruangnya, antara lain [2, 3]:

1. Konsep Keseimbangan (keseimbangan unsur semesta, konsep catur lokapala, konsep dewata nawa sanga), konsep ini juga harus menjadi panutan dalam membangun diberbagai tataran arsitektur termasuk 
keseimbangan dalam berbagai fungsi bangunan. konsep dewata nawa sanga ialah aplikasi dari pura-pura utama yang berada di delapan penjuru arah dibali yang yang dibangun menyeimbangkan pulau bali, purapura utama itu untuk memuja manifestasi tuhan yang berada di delapan penjuru mata angin dan di tengah.Aplikasi konsep ini menjadi pusat yang berwujud natah (halaman tengah) dari sini menentukan nilai zona bangunan yang ada disekitarnya dan juga pemberian nama bangunan disekitarnya seperti Bale Daje, Bale

Dauh, Bale Delod, Bale Dangin. $\bigotimes$

2. Konsep Rwe Bhineda (hulu - teben, purusa - pradana) Hulu Teben merupakan dua kutub berkawan dimana hulu bernilai utama dan teben bernilai nista/ kotor. Sedangkan purusa(jantan) pradana(betina) merupakan embrio suatu kehidupan

3. Konsep Tri Buana - Tri Angga, Susunan tri angga fisik manusia dan struktur tri buana fisik alam semesta melandasi susunan atas bagian kaki, badan, kepala yang masing- masing bernilai nista, madya dan utama.

4. Konsep keharmonisan dengan lingkungan, ini menyangkut pemanfaatan sumber daya alam, pemanfaatan potensi sumber daya manusia setempat, khususnya insaninsan ahli pembangunan tradisional setempat.

\section{DESA ADAT DI BALI}

Buleleng memiliki banyak desa tua yang berderet di dataran tinggi Kecamatan Banjar dan Tejakula. Di Banjar terdapat Desa Sidatapa, Pedawa, Cempaga, Tigawasa dan Banyusri. Di Tejakula masih berdiri dengan unik Desa Sembiran, Julah dan desa lain yang masih berkaitan erat dengan desa-desa tua di Kabupaten Bangli.

Sebagai desa yang bernilai sejarah, tentu saja desa tua ini punya banyak tradisi budaya yang khas, yang patut dipertahankan, bukan semata-mata untuk kepentingan pariwisata, tetapi lebih jauh sebagai aset untuk menelusuri sejarah masa lalu. Masa lalu yang jadi cermin di masa depan.

Memasuki Desa Sidatapa di Kecamatan Banjar, Buleleng, rasanya seperti menyelinap ke dalam sebuah lukisan indah tentang kehidupan Bali masa lalu. Suasana hutan yang sejuk dan jalan setapak yang dikitari gugusan semak dan pepohonan besar senantiasa menawarkan suasana alam yang semakin terkesan liar, namun memberi rasa teduh dan damai. Apalagi ketika masuk ke pemukiman, suasana kehidupan yang polos dan bersahaja tergambar dari gerak-gerik masyarakatnya yang sedikit dingin namun tingkahnya menunjukkan bahwa warga Sidatapa adalah sekelompok warga yang ramah, gampang bersahabat dan mudah diajak bicara.

Desa Sidatapa merupakan salah satu dari deretan desa kuno yang hingga kini masih tersisa di belahan Bali Utara. Orang menyebutnya Desa Bali Aga, sebuah desa yang sudah memiliki otonomi sosial-budaya sebelum Kerajaan Majapahit menancapkan kekuasaannya di Bali. Memang, tak begitu banyak bukti yang bisa menjelaskan secara rinci sejarah desa di ketinggian 600 meter dari atas permukaan laut itu.

Selain cerita sejarah yang dituturkan dari generasi ke generasi, satu bukti penting yang menjelaskan keberadaan desa kuno ini adalah rumah adat yang memang terkesan tua alias kuno. Rumah adatnya di beri nama BALE GAJAH TUMPANG SALU Namun, jika ingin melihat rumah kuno itu secara leluasa, tak cukup dengan hanya menelusuri jalan kecil pedesaan yang sejuk itu. Selain langka, rumah tua itu tidak dibangun menghadap ke jalan sebagaimana rumah modern saat ini. Rumah khas itu dibangun membelakangi jalan sehingga keberadaan cukup tersembunyi.

Banyak cerita unik bisa digambarkan dari keberadaan rumah tua itu yang tentu saja berhubungan erat dengan perjalanan sejarah Bali Kuno secara keseluruhan. Namanya juga rumah kuno, bahan bangunannya tentu sangat bergantung pada alam. Lantai dan temboknya dari tanah, atapnya dari seng, tiang, jendela dan perangkat lainnya dibuat dari bambu batangan atau anyaman bambu.

Yang unik, seluruh bagian ruang rumah tua ini ternyata merangkum semua kehidupan sosial, ekonomi, spiritual, budaya dan keamanan, dari masing-masing keluarga di desa tersebut. Artinya, seluruh kegiatan keluarga dilakukan dalam satu rumah yang memang cukup luas. Jika di Padang, Sumatera Barat, rumah adatnya bernama Rumah Gadang, rumah di Sidatapa juga punya sebutan bagus, yaitu BALE GAJAH TUMPANG SALU, Bale berarti rumah, gajah menunjukkan simbol dari bangunan yang bertiang empat dalam setiap bagiannya, tumpang berarti tingkat dan salu bermakna tiga. Lengkapnya bisa disebut 
sebagai rumah besar yang terdiri atas tiga bagian atau ruangan [3].

Tiga bagian rumah ini memiliki fungsi sosial, ekonomi, spiritual dan budaya yang menjadi satu-kesatuan yang utuh dan saling berhubungan. Bagian utama (utamaning mandala), bagian tengah (madyaning mandala) dan sisi luar (nistaning mandala). Bagian utama dijadikan tempat persembahyangan, tidur, makan, serta tempat menyimpan alat-alat upacara, busana adat, pusaka, emas dan kekayaan lainnya. Bagian tengah digunakan untuk melakukan kegiatan sehari-hari, seperti memasak dan melakukan upacara adat dan upacara keagamaan. Nista mandala adalah daerah luar, lokasi khusus sebagai tempat menerima tamu. Jadi, sejumlah warga mengatakan, rumah tua itu bisa dianggap sebagai pura atau merajan sekaligus sebagai tempat tinggal.

\section{DESA PAKRAMAN JULAH}

Arsitektur Bali sangat kental akan adat dan budayanya. Salah satu yang $\bigotimes$ paling menonjol adalah adanya tempat ibadah (pura) di tiap desa. Ada pula bangunan berupa tempat musyawarah (Bale Banjar), dan tempat tinggal yang masing masing dilengkapi dengan tempat penyimpanan. Tempat tinggal membentuk masa bangunan di dalam suatu pekarangan berdasarkan falsafah dan konsep tata ruang yang mengikuti pedoman dari para undagi.

Denah bangunan berukuran kecil dengan bentuk yang pasti sama, yaitu bujur sangkar atau persegi empat. Tipe bangunan rumah tinggal terbagi menurut jumlah tiang, dari yang terkecil yaitu tiang empat, ada tiang enam, tiang delapan sampai tiang dua belas. Konsep bertingkat (kepala-badan-kaki) masih diterapkan dan dipertahankan di setiap bangunannya. Bagian atap merupakan kepala, dinding dan tiang bangunan merupakan badan, sedangkan lantai merupakan kaki. Bangunan tersebut tahan merupakan bangunan tahan gempa karena elemen konstruksi nya hanya memakai basak, baji, dan tali sehingga mudah pula untuk dibongkar pasang.

Dalam satu hunian dikelilingi oleh pagar tembok, pagar massif yang dipadu dengan candi bentar, dan kori sebagai ekspresi citra tata ruang yang tinggi nilai budayanya. Pagar massif (penyeker) dipercaya sebagai wujud dari perlindungan empat kekuatan alam yaitu air, api, tanah, dan udara yang menempati sudut sudut pekarangan.

Arsitektur tradisional dapat mendekatkan manusia dengan alam lingkungannya. Maka di tiap hunian tradisional Bali, selain adanya rumah tinggal, juga harus terdapat kandang hewan dan beberapa macam tanaman. Dalam "Panacamaha Bhuta" yang merupakan lima usur pokok yang mewujudkan jagat raya ini (makro kosmo) dan manusia (mikro kosmo). Kelima unsur itu adalah apah; teja; bayu; pertiwi; akasa.

Menurut Robbert Geldern, 1982: "hal-hal meta fisik di Asia Tenggara (India, Muangtai, Myanmar, Indonesia) yang berupa konsep keseimbangan antara mikro kosmo dan makro kosmo". Penerapan konsep ini di Bali, arsitek disebut sebagai undagi dan pedoman perancangan karya karya arsitektur. Nilai tata lingkungan juga berdasarkan dalam tingkatan utama, madya, dan nistya (Triloka). Utama adalah tempat suci yaitu Pura, sedangkan pola hunian ada pada madya, dan nistya itu adalah tempat pemandian dan kuburan.

Desa Julah yang merupakan desa tua Bali juga masih sangat menjaga kebudayaan dari para leluhurnya. Pada era modern ini, banyak sedikit pula perubahan yang terjadi pada pola hunian di desa Julah, tetapi tetap tidak berubah pada kebudayaannya. Pola hunian di Desa adat Julah terbagi 2 bagian, yaitu Luan (sakral) dan Teben (Profan). Seperti tergambar pada gambar berikut.

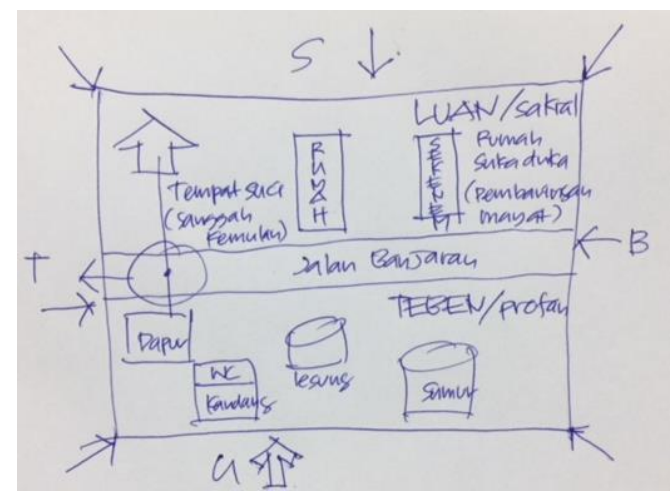

Gambar 1. gambaran skematik pola hunian di Desa Julah

Sumber: Peneliti. 2017

Pada bagian Luan terdapat tempat suci, tempat tinggal, dan sekenem (rumah suka duka/ pembaringan mayat) dan juga ada beberapa jenis kembang boleh tanam. Sedangkan pada bagian Teben terdapat dapur, wc, kandang hewan ternak, lesung, dan juga sumur serta beberapa jenis tumbuhan 
boleh tanam. Yang menghubungkan Luan dan Teben adalah Banjaran.

Ini semua merupakan aturan yang memang sudah ada sejak dahulu kala. Dan tiap hunian menggunakan aturan tersebut. Namun seiring perkembangan zaman, ada kemungkinan banyak terjadi perubahan pada pola hunian tersebut.

\section{ASPEK SOSIAL, EKONOMI DAN BUDAYA}

Ketiga aspek non fisik ini baik secara langsung maupun tidak langsung selalu berkaitan dengan kehidupan masyarakat baik di dalam kehidupan internal sehari-hari maupun eksternalnya. Dalam kehidupan internal masyarakat, ketiga aspek non fisik ini berkaitan dengan perilaku masyarakat yang pada akhirnya berpengaruh dalam pola kegiatan sehari-hari yang tentunya berdampak pada pola ruang yang dibutuhkan dalam kegiatan tersebut. Ada beberapa factor yang mempengaruhi ketiga aspek non fisik tersebut, dan semuanya akan dipaparkan berikut ini.

Faktor-faktor yang mempengaruhi aspek sosial diantaranya adalah $[3,4]$ :

1. Faktor internal merupakan kondisi atau perkembangan yang terjadi dalam lingkungan masyarakat yang bersangkutan mendorong perubahan sosial. Faktor ini meliputi faktor demografis (kependudukan), faktor adanya penemuan-penemuan baru serta faktor konflik internal dalam masyarakat.

2. Faktor eksternal merupakan kondisi atau perkembangan yang terjadi di luar lingkungan masyarakat yang bersangkutan, namun secara langsung maupun tidak langsung mempengaruhi perubahan social dalam masyarakat yang bersangkutan.

Sementara itu aspek ekonomi meliputi hal-hal yang berkaitan dengan mata pencaharian masyarakat. Tingkat perekonomian suatu kawasan tentunya berbeda-beda pada setiap individunya, dan hal ini tentunya juga berdampak pada tingkat perekonomian suatu kelompok masyarakat tertentu dan perkembangan suatu kawasan permukiman.

Dalam kehidupan masyarakat tradisional Bali, tingkat perekonomian suatu kelompok masyarakat digolong-golongkan berdasarkan kasta. Di dalam masyarakat Bali secara umum, terdapat empat tingkatan kasta yaitu yang tertinggi adalah Brahmana, kemudian Ksatriya, Waisya dan yang terendah adalah Sudra.
Namun pada kenyataannya ada beberapa Desa Adat di Bali yang tidak menerapkan empat tingkatan kasta tersebut karena memang kondisi perekonomian di desa tersebut adalah relative homogen, seperti pada Desa Adat Tenganan Pegeringsingan dan Desa Adat Julah.

Aspek yang terakhir yang sangat berpengaruh dalam kehidupan masyarakat adalah aspek budaya. Budaya dapat dikatakan sebagai suatu system nilai yang merupakan hasil hubungan manusia dengan cipta rasa dan karsa yang menumbuhkan gagasan-gagasan utama serta merupakan kekuatan pendukung penggerak kehidupan. Kebudayaan diciptakan oleh factor organobiologis manusia, lingkungan alam, lingkungan psikologis dan lingkungan sejarah.

\section{TEORI-TEORI TERKAIT}

Dalam pelaksanaan penelitian ini, ada beberapa teori yang dapat digunakan dalam proses analisis dan pembahasannya. Teoriteori tersebut adalah:

\section{Teori keterkaitan antara arsitektur dan budaya}

Teori ini digunakan untuk mengkaitkan bagaimana penghuni yang tinggal dan berkegiatan di era modern ini dapat secara optimal memanfaatkan struktur pola ruang hunian tradisional dalam memenuhi kebutuhan ruang sesuai dengan norma social yang berlaku

2. Teori persepsi penghuni terhadap rumah tinggal tradisionalnya

Persepsi penghuni terhadap rumah tinggal tradisionalnya itu sangat dipengaruhi oleh latar belakang dan sifat individu masing-masing seperti budaya, minat, pengalaman, intelektual, agama dan lain-lain. Teori ini akan digunakan untuk menjelaskan bagaiamana dan apa yang melatarbelakangi penghuni melakukan penyesuaian terhadap ruang maupun setting fisik rumah tinggal tradisional

3. Teori hubungan perilaku dan lingkungannya

Perilaku merupakan perwujudan dari hasil persepsi seseorang, dimana setiap individu tentunya memiliki persepsi yang berbeda-beda terhadap suatu hal. Interaksi antara manusia dan lingkungannya merupakan gambaran bentuk hubungan antar tiga sub system lingkungan yaitu individu, organisasi dan setting fisik. 
4. Teori adaptasi dan adjustment

Teori ini menjabarkan tentang perilaku penyesuaian diri untuk mengatasi tekanan lingkungan agar mencapai keseimbangan dan keharmonisan dalam kehidupan berkegiatan berhuni. Penyesuaian adaptasi terkait dengan penyesuaian perilaku terhadap lingkungan yang sudah ada, sementara penyesuaian adjustment terkait dengan perubahan setting fisik atau spasial agar sesuai dengan keinginan atau kebutuhan.

5. Teori proxemic tentang personal space, privacy dan territoriality

Pada dasarnya teori ini merupakan upaya perlindungan diri terhadap intervensi dari orang lain yang tidak dikehendaki. Personal space memiliki batas maya mengikuti individu, terkait keintiman sesorang dengan orang lain. Privacy adalah inti dari personal space yaitu kecenderungan untuk tidak ingin diganggu dalam kesendiriannya. Sementara territoriality memiliki batas ruang fisik yang dibuat untuk tujuan privasi individu dan kelompok yang terkait dengan hak kepemilikan. Teori ini akan membantu dalam proses analisa hirarki ruang, orientasi bangunan dan penetapan batas teritori hunian.

\section{METODE PENELITIAN}

Dalam penelitian ini, proses analisis dan pembahasannya akan menggunakan metode deduktif komparatif. Pendekatan deduktif adalah pendekatan secara teoritis untuk mendapatkan konfirmasi berdasarkan hipotesis dan observasi yang telah dilakukan sebelumnya. Suatu hipotesa lahir dari sebuah teori yang kemudian diuji dengan melakukan beberapa observasi. Hasil dari observasi itulah yang akan memberikan konfirmasi tentang sebuah teori yang semula digunakan untuk menghasilkan hipotesa.

Sementara itu pendekatan komparatif adalah pendekatan dengan sifat membandingkan satu kasus dengan kasus lainnya. Penelitian ini menggunakan metode ini untuk membandingkan persamaan dan perbedaan dua atau lebih fakta-fakta dan sifat-sifat obyek studi kasus yang diteliti berdasarkan kerangka pemikiran tertentu.

\section{TEMUAN DAN HASIL}

\section{Pengaruh Aspek Sosial Terhadap Pola Permukiman Desa Adat Julah Menurut Strata Sosial}

Strata sosial desa adat Julah ditentukan pada tingkat kepemimpinan seseorang, adapun pembagiannya adalah sebagai berikut: Bendesa adat, Kelian adat, Penyarikan desa dan golongan masyarakat biasa. Tingkat golongan tersebut tidak mempengaruhi dimana orang tersebut akan tinggal. Setiap masyarakat desa bebas untuk tinggal di kelompok permukiman manapun. Hal inilah yang menjadikan bentuk pola permukiman desa adat Julah bersifat homogen, yaitu memiliki bentuk yang sama dan tidak ada perbedaan bentuk dibagian tertentu.

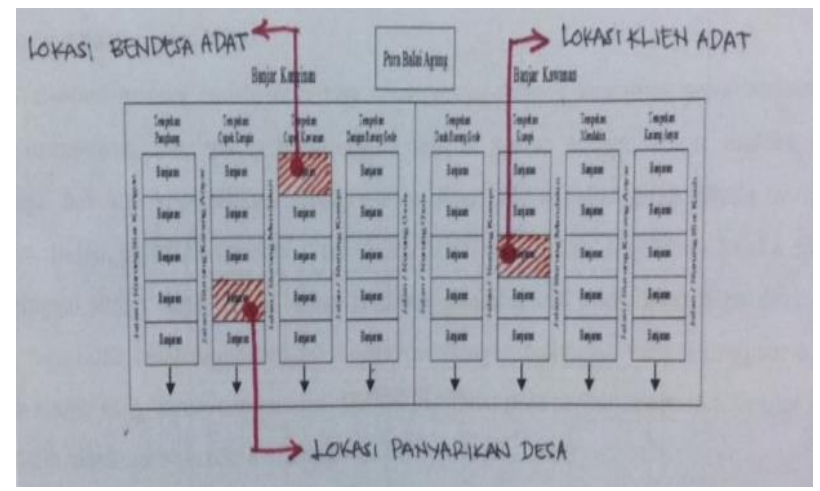

Gambar 2. Lokasi Rumah Tinggal Pejabat Desa Sumber: Hasil Analisa, 2017

\section{Organisasi Desa Dinas}

Sama halnya dengan pola permukiman modern, pengelompokkan permukiman berdasarkan organisasi desa dinas, yakni terdapat RW dan RT.

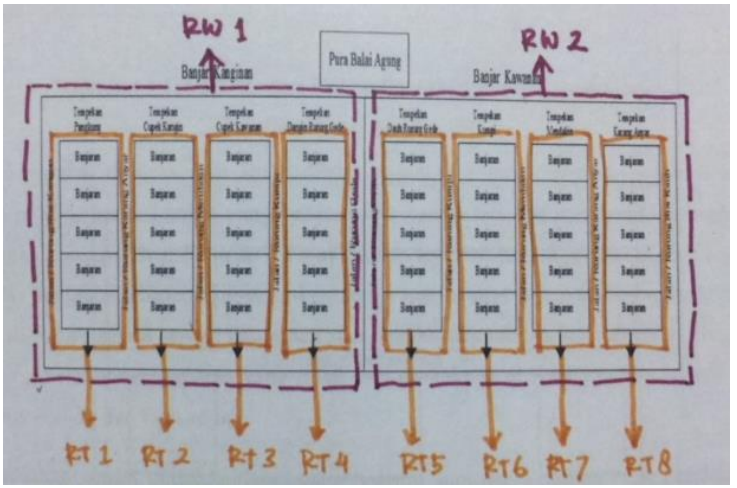

Gambar 3. Pola Permukiman Membentuk Organisasi Desa Dinas

Sumber: Hasil Analisis, 2017

Dalam 1 banjar terdiri dari 4 tempekan yang masih dibawah koordinasi banjar. 1 banjar di desa adat Julah merupakan lingkup $1 \mathrm{RW}$, 
sehingga di desa ini terdapat 2 RW. Kemudiaan di setiap tempekan terdiri dai 1020 banjaran, dimana banjaran tersebut merupakan lingkup 1 RT yang terdiri dari 8 $15 \mathrm{kk}$.

\section{Pengaruh Aspek Sosial Terhadap Pola Hunian Desa Adat Julah Zonasi Pola Hunian}

Perletakan hunian yang berdasarkan zonasi tersebut dipengaruhi oleh kegiatan keseharian si penghuni, dimana kegiatan-kegiatan yang bersifat sakral atau yang bersifat suci diletakkan di zonasi sakral seperti bangunan suci, rumah tinggal dan bale sekenem. Kegiatan yang bersifat service atau yang tidak suci diletakkan di zonasi profan seperti paon, toilet, jineng, resung dan juga sumur. Pemisahan zonasi untuk kegiatan yang bersifat suci dan kegiatan yang bersifat tidak suci ini bertujuan agar kegiatan-kegiatan sosial si penghuni tidak tercampur.

\section{Penambahan Unit Hunian}

Salah satu pola hunian yang menambahkan unit hunian nya di daerah teben, si penghuni menambahkan sebuah bangunan terbuka yang mempunyai 6 tiang penyangga. Penambahan unit hunian ini disebabkan karena penghuni rumah ini adalah seorang kepala adat yang hampir tiap hari menerima tamu dari dalam maupun luar desa, sehingga keberadaan unit hunian ini berfungsi sebagai penerima tamu atau bisa digunakan sebagai tempat musyawarah desa.

\section{Pengaruh Aspek Ekonomi Terhadap Pola Permukiman Desa Adat Julah}

Dalam agama Hindu terdapat tingkatan kasta, diantaranya Brahmana (golongan rohaniawan), Ksatriya (golongan para bangsawan), Waisya (golongan para pedagang, petani, nelayan dan profesi lainnya), dan Sudra (golongan para pelayan).

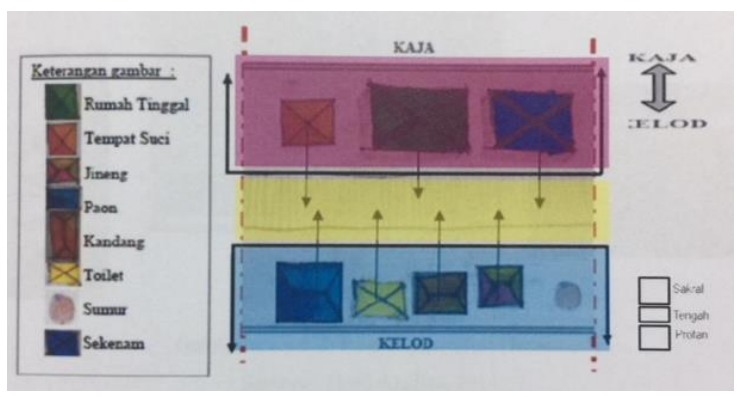

Gambar 4. Zonasi Pola Hunian Sumber: Hasil Analisis, 2017

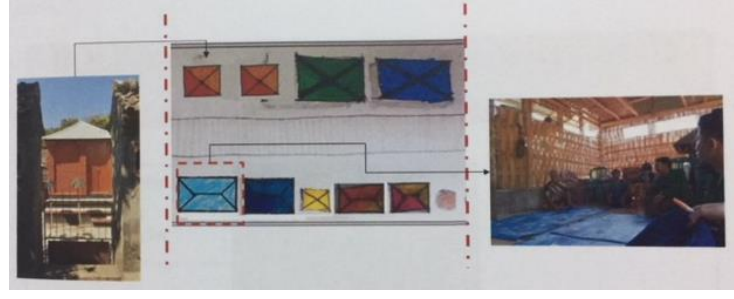

\section{Gambar 5. Penambahan Unit Hunian} Sumber: Hasil Analisis, 2017

Dalam agama Hindu terdapat tingkatan kasta, diantaranya brahmana (golongan rohaniawan), ksatriya (golongan para bangsawan), waisya (golongan para pedagang, petani, nelayan dan profesi lainnya) dan sudra (golongan para pelayan). Walaupun terdapat tingkatan kasta tersebut tetapi masyarakat desa adat Julah tidak membedakan pola permukimannya. Orang yang memiliki tingkatan ekonomi tinggi ataupun orang yang memiliki tingkatan ekonomi rendah berhak tinggal di kelompok permukiman mana saja.

\section{PENGARUH ASPEK EKONOMI TERHADAP POLA HUNIAN DESA ADAT JULAH Jumlah Unit Hunian}

Ada perbedaan antara masyarakat yang mampu dan masyarakat yang kurang mampu, perbedaan tersebut terletak pada jumlah unit dalam satu pola hunian. Umumnya dalam satu pola hunian desa adat Julah terdapat bangunan suci, bale, sekenem, paon, toilet, resung, jineng dan sumur. Tetapi pada gambar di atas terlihat bahwa satu pola hunian tersebut hanya terdapat bangunan bale, bangunan suci, sumur, toilet dan paon. Ini menunjukkan bahwa pemilik pola hunian tersebut mempunyai tingkatan ekonomi yang rendah. Jumlah unit hunian dalam satu pola hunian menunjukkan kemampuan si penghuni dalam membangun.

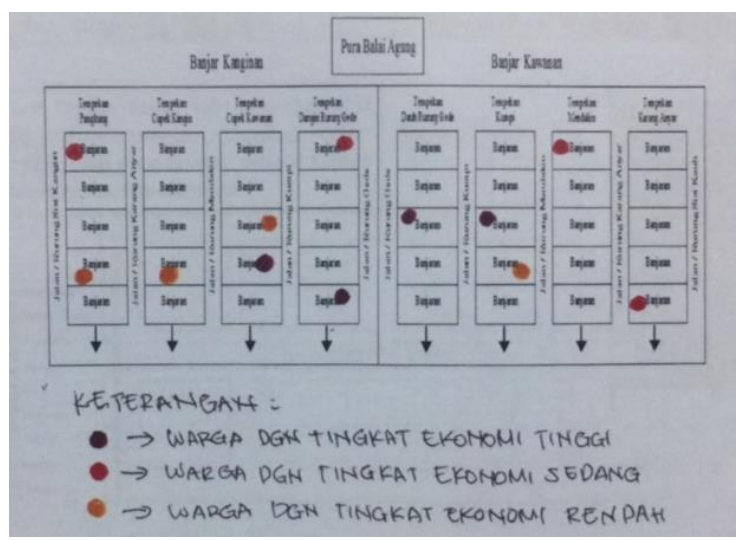

Gambar 6. Tingkatan Ekonomi Penduduk Sumber: Hasil Analisis, 2017 


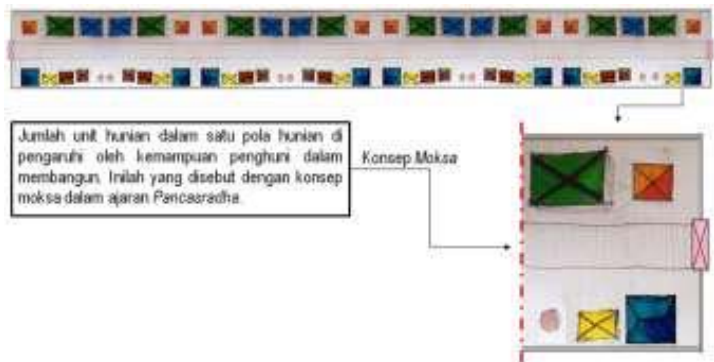

Gambar 7. Jumlah Unit Hunian Yang Disebabkan Faktor Ekonomi

Sumber: Hasil Analisis, 2017

\section{Pengaruh Aspek Budaya Terhadap Pola Permukiman Desa Adat Julah \\ Filosofi "Nyegara Gunung"}

Nyegara Gunung" berhubungan dengan orientasi kosmologis, dimana orientasi kosmologis itu terbagi atas dua sifat, yaitu yang bersifat sakral dan bersifat profan. Kedua hal tersebut merupakan perbedaan struktur wilayah yang menandakan tingkat kesakralan.

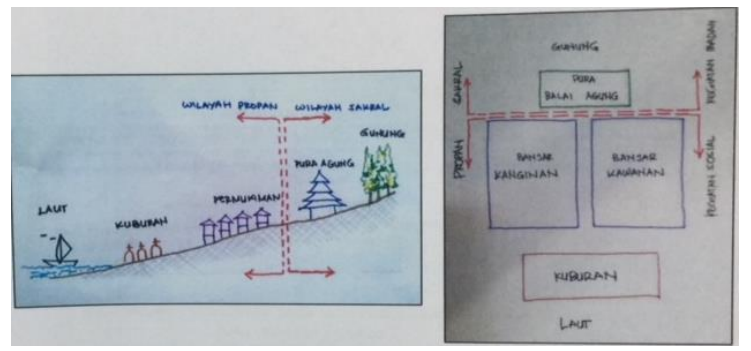

Gambar 8. Orientasi Kosmologis Pada Pola Permukiman Desa Adat Julah Sumber: Hasil Analisis, 2017

\section{Tri Hita Kirana}

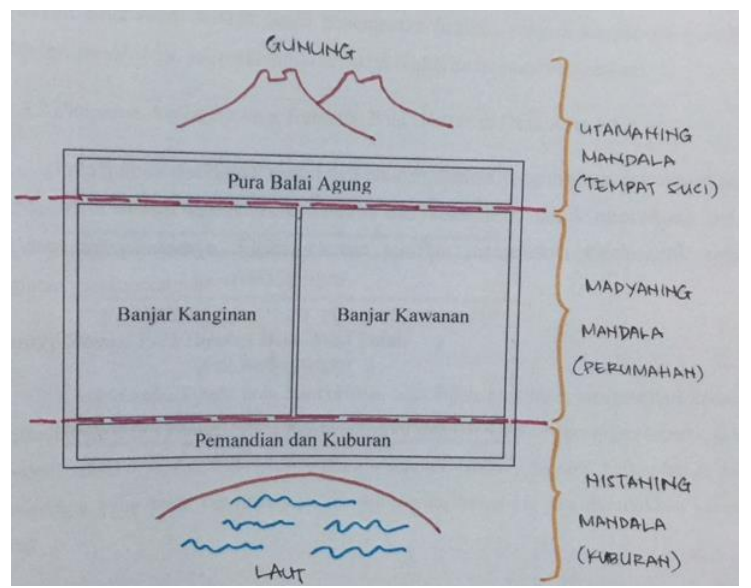

Gambar 9. Tiga Palemahan Pola Permukiman Desa Adat Julah

Sumber: Hasil Analisis, 2017

Untuk konsep pola permukiman desa adat Julah mengikuti kaidah- kaidah yang bersifat umum seperti kaidah orientasi, tinggi rendah suatu tempat dan tingkatan nilai ruang.
Dataran yang lebih tinggi memiliki nilai utama, daerah dataran (tengah) memiliki nilai madya dan daerah dataran rendah (ke arah laut) memiliki nilai nista. Berdasarkan kaidahkaidah tersebut pola permukiman desa adat Julah terdiri dari tiga pelemahan (alam tempat manusia hidup dan berkehidupan) yaitu Palemahan utamaning mandala yang diperuntukkan sebagai area tempat suci, palemahan madyaning mandala diperuntukan sebagai area perumahan dan nistaning mandala diperuntukan sebagai tempat kuburan ataupun pemandian. Hirarki tersebut ditempatkan berdasarkan kondisi geografis dari wilayahnya.

\section{Pengaruh Aspek Budaya Terhadap Pola Hunian Desa Adat Julah Konsep Zonasi}

Konsep zonasi pola hunian desa adat Julah tidak terlepas dari konsep agama Hindu yaitu konsep "Rwa Bhineda" yaitu dua hal yang bertentangan seperti; luan-teben; sakralprofan, hulu-hilir; utara- selata; positif-negatif; dan sebagainya. Zonasi tersebut membentuk pola linier yang dipisah oleh jalan kecil atau biasa disebut dengan rurung jalan yang lebarnya hanya $100 \mathrm{~cm}$. Ketika pola linier terbentuk dalam suatu pola hunian konsep "Nawa Sanga" tidak begitu berperan. Orientasi kosmologi lebih didominasi oleh sumbu kajakelod (utara-selatan).

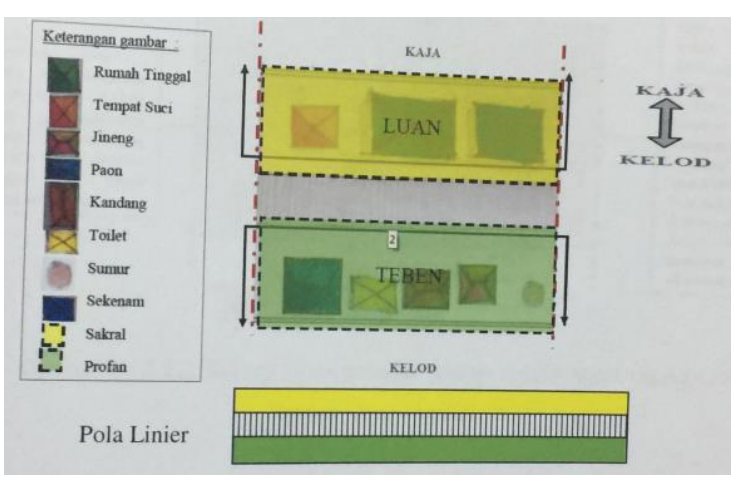

\section{Gambar 10. Konsep Zonasi Pola Hunian} Desa Adat Julah

Sumber: Hasil Analisis, 2017

\section{Konsep Pancasradha}

Pola hunian desa adat Julah pada umumnya mempunyai konsep tata ruang tradisional Bali yang sangat kental. Dalam aspek agama Hindu pola hunian desa adat Julah dijiwai oleh ajaran Pancasradha yang terdiri dari brahma, atma, reinkarnasi, karmapala dan moksa. 


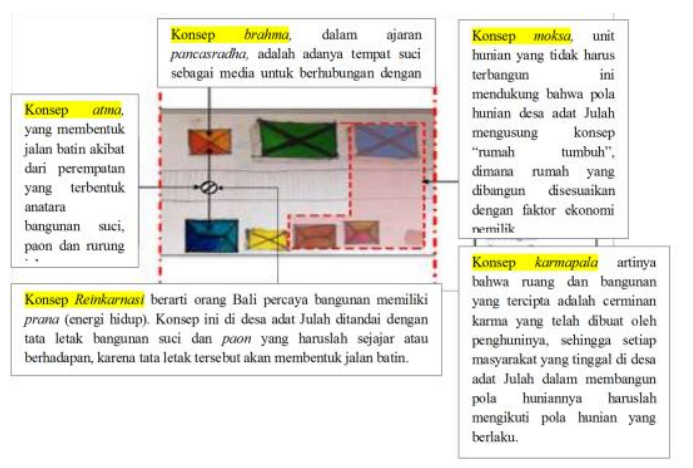

Gambar 11. Konsep "Pancasradha" Pada Pola Hunian Desa Adat Julah Sumber: Hasil Analisis, 2017

\section{KESIMPULAN}

Aspek sosial tidak mempengaruhi pola permukiman desa adat Julah dari segi strata sosialnya. Tetapi dari segi terbentuknya organisasi desa dinas mempengaruhi pola permukiman desa adat Julah dimana adanya pembagian kelompok RT dan RW yang berdasarkan banjar, tempekan dan banjaran. Aspek sosial mempengaruhi letak unit hunian yang berdasarkan zonasi sakral dan zonasi profan.

Aspek ekonomi tidak mempengaruhi pola permukiman desa adat Julah, karena pola permukiman yang terbentuk tidak mengkelompokkan masyarakat berdasarkan tingkat ekonomi seseorang. Aspek ekonomi mempengaruhi jumlah unit hunian dalam satu pola hunian. Jumlah unit hunian dipengaruhi oleh kemampuan si penghuni dalam membangun.

Aspek budaya mempengaruhi pola permukiman dari segi filosofi "Nyegara Gunung" berpengaruh pada zona profan dan zona sakral. Sedangkan Tri Hita Karana berpengaruh pada pembagian zona utama, zona madya dan zona nista. Aspek budaya mempengaruhi konsep "Rwa Bhineda" yang membentuk pola zonasi, dan konsep "Pancasradha" yang mempengaruhi tata ruang pola hunian

\section{REFERENSI}

[1] Setiawan, I Ketut. (2011). Dampak Sosial Ekonomi Dan Sosial Budaya Pemanfaatan Pura Tirta Empul Sebagai Daya Tarik Wisata Budaya. Universitas Udayana. Bali.

[2] Dwijendra, Ngakan Ketut Acwin. (Oktober
2008). Arsitektur Rumah Tradisional Bali. Penerbit Udayana University Press bekerjasama dengan CV Bali Media Adhikarsa.

[3] Suyasa, Wayan. (2012). Desa Julah Yang Bertahan. 27 September 2014 dari http://wayansuyasawebblog.blogspot.com/2012/10/desa-julahyang-bertahan.html?m=1

[4] Tri Cahyono, Agus. (2002). Strategi Penyesuaian Rumah Tradisional dan Pengaruhnya Terhadap Pola Hunian di Kotagede. Universitas Diponegoro. Semarang.

[5] Turner, John FC. (1972). Freedom to Build: Dweller Control of the Housing Process. The Macmillan Company. New York. 
Halaman ini sengaja dikosongkan 